\title{
Expression of the of STRO-1 and HSP-25 markers during odontogenesis
}

\author{
Expressão dos marcadores STRO-1 e HSP-25 \\ durante a odontogênese
}

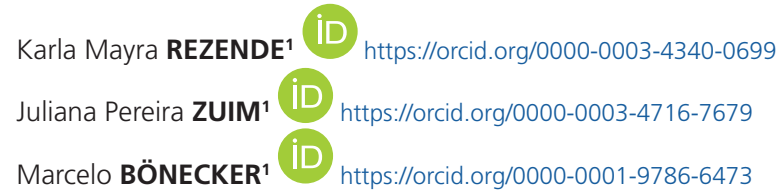

\section{ABSTRACT}

Objective: Therefore, the purpose of the currently study was to analyze the expression of the STRO-1 stem cell marker and the marker related to Hsp25 differentiation and dental development during odontogenesis in rats. Methods: Eighteen-day Wistar rat embryos and 7-day-old animals were analyzed morphologically via Hematoxylin and Eosin (HE) staining and via immunohistochemical marking for Stro-1 and Hsp25 in 5uM serial sections. Results: In the HE morphological analysis in 18-day embryos, the stage of tooth development was in the cap phase, while in the 7-day old animals it was in the bell phase. Conclusion: The expression of STRO-1 in the embryos was not found in the region of the dental papilla or enamel organ, however, in the 7-day-old animals, STRO-1-positive cells were found in the region of the dental follicle and dental papilla. As for the Hsp25, this exhibited weak marking in the cap phase while in the bell phase, there was a reaction, mainly in the odontoblasts. The expressions in the site of these markers vary according to the stage of tooth development.

Indexing terms: Immunohistochemistry. Odontogenesis. Stem cells. Tooth.

\section{RESUMO}

Objetivo: Analisar a expressão do marcador de células-tronco STRO-1 e o marcador relacionado à diferenciação da Hsp25 e ao desenvolvimento dental durante a odontogênese em ratos. Métodos: Embriões de ratos Wistar de dezoito dias e animais de sete dias de idade foram analisados morfologicamente através da coloração com Hematoxilina e Eosina (HE) e através de marcação imuno-histoquímica para STRO-1 e Hsp25 em seções seriais de 5uM. Resultados: Na análise morfológica da HE em embriões de 18 dias, o estágio de desenvolvimento dos dentes estava na fase capuz, enquanto nos animais de 7 dias estava na fase de campânula. Conclusão: Nos embriões, a expressão de STRO-1 não foi encontrada na região da papila dentária ou no órgão do esmalte; no entanto, nos animais de sete dias de idade, células positivas para STRO-1 estava presente na região do folículo e papila dentária. Quanto ao Hsp25, este apresentou fraca marcação na fase capuz, enquanto na fase campânula houve reação, principalmente nos odontoblastos. As expressões no local desses marcadores variam de acordo com o estágio do desenvolvimento dentário.

Termos de indexação: Imuno-histoquímica. Odontogênese. Células-tronco. Dente.

\footnotetext{
1 Universidade de São Paulo, Faculdade de Odontologia, Departamento de Ortodontia e Odontopediatria. Av. Prof. Lineu Prestes, 2227, 05508-900, São Paulo, SP, Brasil. Correspondende to: KM REZENDE. E-mail: <karla.rezende@usp.br>.

$\boldsymbol{\nabla} \mathbf{v} \boldsymbol{v}$

How to cite this article

Rezende KM, Zuim JP, Bönecker M. Expression of the of STRO-1 and HSP-25 markers during odontogenesis. RGO, Rev Gaúch Odontol. 2021;69:e20210054. http://dx.doi.org/10.1590/1981-863720210005420200017
} 


\section{INTRODUCTION}

The major differentiation potential of dental stem cells lies in the formation of dentin and tissue associated with the periodontium, regardless of whether these cells are derived from the pulp, apical papilla, periodontal ligament or dental follicle [1-3].

The identification and isolation of adult stem cells in the dental pulp of human teeth was described initially by Gronthos et al. in 2000 [4].This study group identified stem cells by virtue of their clonogenic abilities, rapid proliferation and the ability to form mineralized tissue, both in vitro and in vivo.

In 2003, Shi \& Gronthos [5] isolated human stem cells from the bone marrow and dental pulp through the STRO-1, a specific mesenchymal stem-cell marker, and analyzed the expression of antigens in the endothelial cells, smooth muscle pericytes. The authors concluded that the cell populations in both tissues are associated with the microcirculation of the tissues in which they reside.

Cells from the apical papilla of the third molars have also been studied using STRO-1 as a marker of mesenchymal stem cells $[6,7]$. For Huang et al. [8], this line of evidence suggests that cells in the apical papilla derive from developing tissue which represents a young stem-cell population, in other words, a superior source of cells for the regeneration of tissue. In addition, this demonstrates the important aspect that the developing tissue may contain stem cells different from the already formed tissue.

Mesenchymal stem cells share a series of markers with hematopoietic cells, therefore the identification of specific markers for mesenchymal cells is shown to be important. The STRO-1 (stromal-derived factor-1 antigen) is a marker that is imperative for the isolation and identification of mesenchymal stem cells. The anti-STRO- 1 antibody reacts with the surface cell antigen expressed by precursor cells of the bone marrow stroma, and is minimally reactive with the hematopoietic cells [9]. However, the gene, molecular structure and the STRO-1 antigen function have not yet been fully defined [10].

Kaneko et al. [10] studied the immunolocalization of STRO- 1 in the teeth of developing rats. The pulp cells of the crown showed a less intense marking when compared to those of the root; the pulp cells in the apical region showed no marking. Some pulp and perivascular cells remained positive in the final stage of root formation.
Similarly, osteoblasts, cementoblasts and cells from the periodontal ligament were immunoreactive. The authors suggest that the STRO-1 is related to the differentiation of mesenchymal cells and formation of the dental tissue matrix. Moreover, the identification of STRO-1-positive pulp cells near the HERS (Hertwig epithelial root sheath) was not observed.

Sonoyama et al. [11] identified in developing human teeth the expression of STRO-1 in the cells of the apical papilla. As a result, the authors conclude that mesenchymal stem cells reside in the apical papilla, since they expressed a variety of markers for this cell type. Moreover, these cells were capable of differentiating into cells of the odontoblast type and producing dentin in vitro. There was joint expression of STRO-1 with dentinogenic markers such as bone sialophosphoprotein, osteocalcin and FGFR1 growth factors (Fibroblast Growth Factor Receptor 1) and TGFBRI (Transforming Growth Factor- $B$ Receptor Type 1). These findings suggest that the marked cells are of primary odontoblast origin that form root dentin.

Miura et al. [12] reported that stem cells from human exfoliated deciduous teeth (SHEDs) exhibited markings with both STRO-1 and CD146, which is also a mesenchymal precursor cell marker. The authors found that these antibody-positive cells were located close to the blood vessels of the remaining pulp tissue.

Heat-shock protein-25 is a class of proteins that belongs to a small family of HSPs equivalent to human protein Hsp27, functionally involved in the evolution of other proteins [13]. Heat shock proteins serve to protect cells against damage induced by physiological stress, including heat shock, oxidative stress, high temperatures and noxious chemicals $[14,15]$. In mammals, HSP-25 is phosphorylated during the beginning of the differentiation of various cells, such as carcinoma and stem cell [16].

In oral tissue, there is a very close relationship between the end of the cell proliferation and expression of Hsp25, demonstrated by way of immune marking in cells like odontoblasts, fibroblasts and on the vascular wall of endothelial cells of third-molar dental pulp after completing cell division, suggesting that this protein acts as a switch between cell differentiation and differentiation during tooth development [17-19]. However, there are no available data with regard to the relationship between cell proliferation and differentiation. 
The way to define and identify a stem cell has been constantly evolving, yet there is still no consensus over a method that can be considered a "gold standard" for this type of identification $[20,21]$. In both embryonic and adult stem cells, different markers have been described. Some, like alkaline phosphatase, are common to different cell types $[22,23]$, however, specific markers for the exclusive identification of a particular completely undifferentiated cell or from a similar lineage, are still lacking. Odontogenesis consists of a dynamic process coordinated by the reciprocal interaction of the epithelium (enamel organ) and ectomesenchyme (dental papilla and dental follicle) leading to cell morphogenesis and differentiation in the tooth bud, ending up with the deposit of dental tissue. The localization of STRO-1-positive cells has not been established.

Therefore, the proposal of the present study is to localize, through an immunohistochemical study, the localization of STRO-1-positive cells during odontogenesis. The objective of this study was to prepare a morphological analysis of the distribution of the presence of STRO-1 and Hsp25 markers during odontogenesis, in order to identify stem cells in these tissues.

\section{METHODS}

For the present study, the experiments were conducted in accordance with the principles of care for laboratory animals (NIH Publication no. 86-23, 1985) and national legislation on the use of animals, and was approved by the Animal Research Ethics Committee under opinion no. 018/2013.

\section{Acquisition of specimens}

For the mating of the males and females, in a ratio of $1: 1$, they were kept together for one night and separated in the morning, at which point, with the help of cotton buds, vaginal smears were performed to check for the presence, or otherwise, of sperm cells.

The smears, after fixing in ethyl alcohol, were stained using the Shorr technique (1941) and examined under a light microscope. The presence of sperm cells in the smears was established on the first day of gestation.

\section{Euthanasia}

Euthanasia of the females at 18 days gestation was carried out through the inhalation of carbonic gas. Then a caesarian section was performed to remove the embryos.

The fetuses were removed quickly and put down by way of decapitation and the alveolar processes of the maxilla were removed. The removal of the alveolar processes of the 7-day-old animals was through decapitation. In both forms, after removal, the parts were swiftly immersed in a fixing by $4 \%$ paraformaldehyde solution.

\section{Light microscopy}

The maxillary alveolar processes were divided through the palatal ridge. After 24 hours of fixation, the material was decalcified in EDTA at $4.12 \% \mathrm{pH} 7.2$, for three weeks, the solution being refreshed every three days. Finally, the parts were dehydrated in increasing concentrations of alcohol and soaked in paraffin.

The sections were cut using a sliding microtome (Leica, SM2000 R, Germany) and mounted on glass slides which had been deparaffinized in ovens at $60^{\circ} \mathrm{C}$ and then in xylene, hydrated and stained with hematoxylin and eosin and subsequently mounted on cover slips with Entellan (Merck). The sections were examined and photographed under a Nikon Eclipse optical microscope (TS100 NISElements $\mathrm{D}$ live).

\section{Immunohistochemistry for detecting STRO-1 and Hsp25}

The slides were heated to $600 \mathrm{C}$ for 30 minutes for the start of the deparaffinization. They then underwent two xylene baths, two baths of absolute alcohol, one of $96 \%$ alcohol and another in $75 \%$ alcohol. The slides were washed in PBS and incubated in an antigen retrieval solution, using citric acid for the STRO-1 and EDTA for the Hsp25, for 20 minutes. For the endogenous peroxidase blocking, the slides were immersed in hydrogen peroxide (20 volumes) in methanol in a ratio of 1:1, performing two 15-minute baths. The slides were then washed in distilled water in two 5-minute baths. The buffering was carried out using TRIS with three 5-minute baths and nonspecific site blocking was performed. The incubation with STRO-1 (Mouse anti-STRO-1, Invitrogen, CA, USA) was at a dilution 
of 1:50 for 1 hour. For the Hsp25 (Abcam plc, Cambridge, UK) the dilution was 1:300 and was left overnight, after which secondary incubation was performed with Advance streptavidin-biotin (Kit DAKO, DAKO, CO, USA) for 30 minutes. Lastly, a counterstaining was carried out using Harris-modified hematoxylin and the slides were mounted for analysis.

\section{RESULTS}

\section{Morphological analysis}

The sections stained with hematoxylin and eosin showed cap stage and bell stage. In the 18-day-old embryos, the tooth development stage was in the bell phase. As for the 7-day-old animals, they were in the crown formation phase (figure 1).
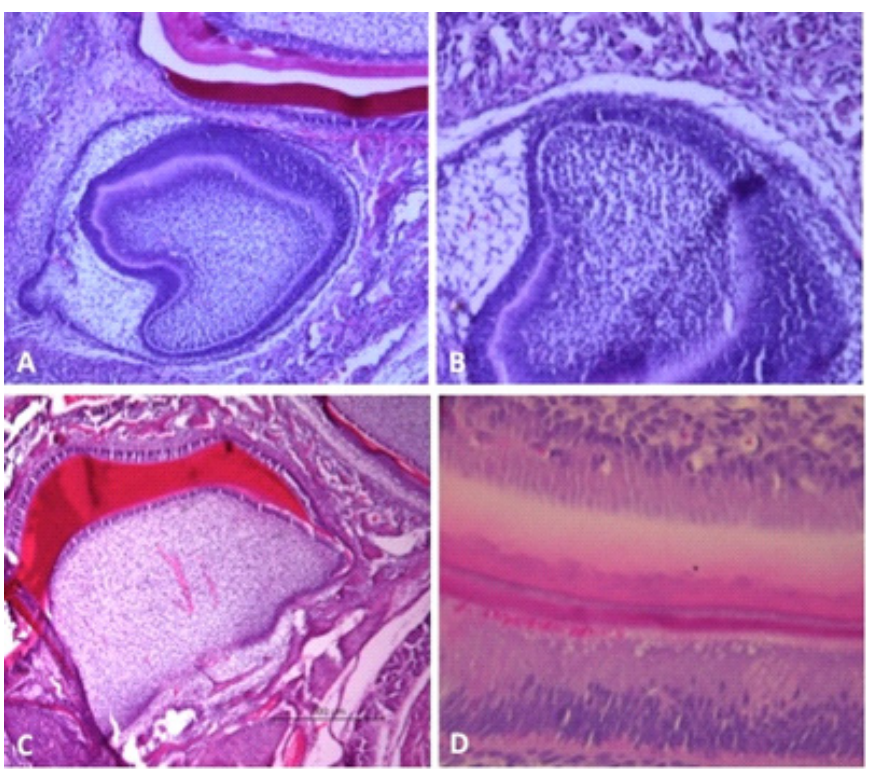

Figure 1. Morphological view of the stages of tooth formation. In $A$, the bell phase (40x) and B, increased magnification (100x). In C, crown phase (40x) and D, increased magnification (400x) showing the stage of dentinogenesis and amelogenesis.

The study of the immunoreaction of the STRO-1 and Hsp25 was carried out in descriptive fashion through two calibrated examiners, based on the images observed.

Figure 2 shows the STRO- 1 reaction in the two groups. In the embryos with 18 days of development, no
STRO-1 reaction was observed in the dental papilla or enamel organ. However, the cells in the region of the formation of the alveolar process (osteogenic) positive marking was found. In the 7-day-old group, STRO-1 marking was seen in the blood vessels and cells. Positive marking was also observed in the odontoblasts in the dentinogenesis phase.
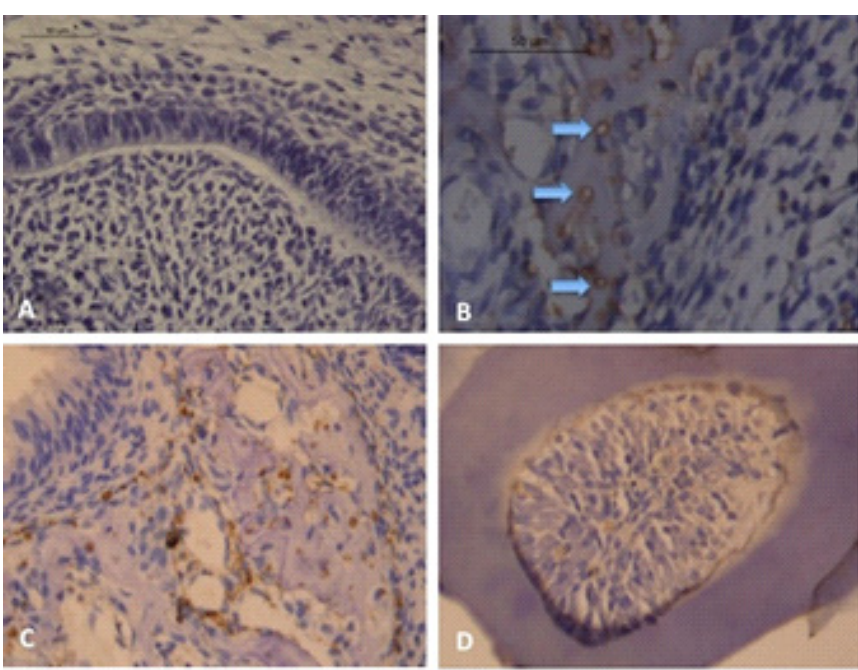

Figure 2. STRO-1 marking. In A, Embryonic phase, absent in the apical papilla phase. In B, Embryonic phase, positive marking in the osteogenic region. C- Seven-day-old animals. Blood vessels (100x) and odontoblast region (40x).

The Hsp25 marking varied its expression according to the stage of odontogenesis. It was heavily identified in the region of dentinogenesis and amelogenesis, and weakly in the region of the papilla and enamel organ in the embryonic phase. This shows that the Hsp25 seems to be regulated in a time-dependent fashion, during the development and differentiation of the tooth bud (figure 3).

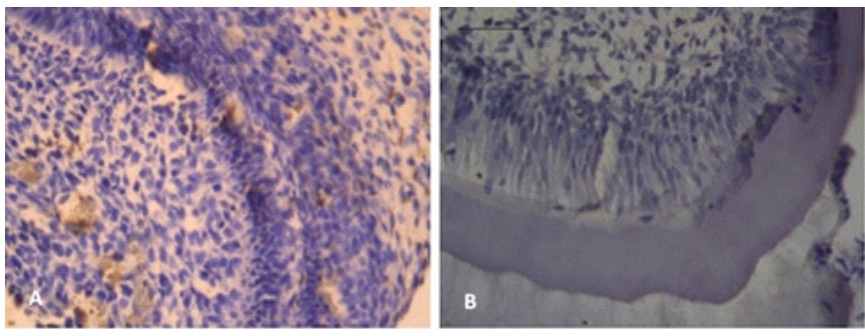

Figure 3. Hsp25 - weak marking in the bell phase and positive, mainly in the odontoblasts. 


\section{DISCUSSION}

The path which a cell takes, from the embryological state to differentiation comprises a sequence of genecontrolled expressions and repressions [20]. Which mechanisms and how they come together to bring the organism into being, are the core problems of the biology of development [21].

STRO-1 is a cell surface marker. The positive population for this antibody has shown that stem cells of mesenchymal origin are present. In dentistry, the existence of stem cells in the various dental tissues is well known [3]. However, the localization of this antibody during tooth development has not yet been established.

Many cell stress situations can cause an increase in the expression of HSPs, such as glucose deprivation, contact with bacterial toxins and heavy metals, oxidative stress and situations of tissue repair and cell differentiation in which there are large volumes of cell proliferation and differentiation activity [24]. In this study, the histological and immunolocalization characteristics were evaluated of a stem-cell marker (STRO-1) and a cell proliferation and differentiation marker (Hsp25), in rat teeth, during the bell and crown phases [25]. Tissue evaluation through immunohistochemistry enables cell characteristics to be identified through their reactivity to specific antibodies. Even though the literature shows the use of STRO-1 to identify stem cells in human dental pulp [5] and apical papilla extracted from human third molars [6], we did not observe their presence in the region of the apical papilla. However, the model employed in the present study differs from the one used by authors who obtained positive marking. The antibody for identifying the STRO-1 molecule is specific for reactions in humankind. However, Kaneko et al. [10] used this marker in the teeth of Wistar rats, finding positive marking in bone marrow cells, odontoblasts and the pulp cells in the final stages of the formation of crowns and roots, osteoblasts, cementoblasts and cells of the periodontal ligament. It maintained immunoreactivity in some perivascular cells, suggesting that STRO-1 is characteristic of some cells of mesenchymal lineage that have already undergone differentiation [3]. As far as the Hsp25 is concerned, this study demonstrated that it acts as a switch between cell proliferation and differentiation during odontogenesis $[17,18]$. This is clearly seen in the constant, intense reactions along the entire length of the dentin deposition in the region of the odontoblasts.
Odontoblasts are cells that secrete the proteins responsible for the activation of dentinogenesis, and this occurs because they possess a high concentration of RNA and proteins in their cytoplasm. The HSP marker pool in the odontoblasts suggests the triggering of the Hsp25 as a molecule during this phase. This leads to a hypothesis that the expression of Hsp25 in the odontoblasts may be regarded as a response to stress through the modulation of the activation of the dynamics of apoptosis regulation[14]. Thus, it also explains why it was not observed in the initial stages of odontogenesis. Numerous cells in proliferation in the development of molar teeth were marked by the Hsp25 in the cell differentiation phase. These results are basically consistent with the literature [14-19].

Despite the limitations related to the extrapolation of the results to human beings, the species chosen for the model has molar teeth, tissue and development similar to that of the human being [26]. Therefore, an additional study could lead to a better understanding of the function of these molecules and their relationship with stem cells.

\section{CONCLUSION}

The localization of these markers has expressions that vary according to the stage of odontogenesis.

The immunohistochemical technique was not sufficient to evaluate the presence of stem cells during odontogenesis. Therefore, further studies should be conducted using the same markers, though applying more sensitive molecular techniques, which complement immunohistochemistry.

\section{Collaborators}

$M$ REZENDE and JP ZUIM, investigation (equal), methodology (equal). M BÖNECKER, supervision (equal), visualization (equal), writing-review \& editing (equal).

\section{REFERENCES}

1. Liu J, Yu F, Sun Y, Jiang B, Zhang W, Yang J, et al. Concise reviews: characteristics and potential applications of human dental tissue-derived mesenchymal stem cells. Stem Cells. 2015;33(3):627-638. https//dx.doi.org/10.1002/stem.1909

2. Yang B, Qiu Y, Zhou N, Ouyang H, Ding J, Cheng B, et al. Application of Stem cells in oral disease therapy: progresses and perspectives. Front Physiol. 2017;8:197. https//dx.doi. org/10.3389/fphys.2017.00197 
3. Homayounfar N, Verma P, Nosrat A, El Ayachi I, Yu Z, Romberg $E$, et al. Isolation, characterization, and differentiation of dental pulp stem cells in ferrets. J Endod. 2016;42(3):418-424. https//dx.doi.org/10.1016/j.joen.2015.12.002

4. Gronthos S, Mankani M, Brahim J, Robey PG, Shi S. Postnatal human dental pulp stem cells (DPSCs) in vitro and in vivo. Proc Natl Acad Sci USA. 2000;97(25):13625-30. https//dx.doi.org/ 10.1073/pnas.240309797

5. Shi S, Gronthos S. Perivascular niche of postnatal mesenchymal stem cells in human bone marrow and dental pulp. J Bone Miner Res. 2003;18(4):696-704.

6. Sonoyama W, Liu Y, Fang D, Yamaza T, Seo BM, Zhang C, et al. Mesenchymal stem cell-mediated functional tooth regeneration in swine. PLoS One. 2006;1(1):e79. https// dx.doi.org/10.1371/journal.pone.0000079

7. Jo Y-Y, Lee HJ, Kook SY, Choung HW, Park JY, Chung JH, et al. Isolation and characterization of postnatal stem cells from human dental tissues. Tissue Eng. 2007;13(4):767-773. https//dx.doi.org/10.1089/ten.2006.0192

8. Huang GT, Sonoyama W, Liu Y, Liu H, Wang S, Shi S. The hidden treasure in apical papilla: the potential role in pulp/dentin regeneration and bioroot engineering. J Endod. 2008;34(6):645-651. https//dx.doi.org/10.1016/j. joen.2008.03.001

9. Friedlander LT, Cullinan MP, Love RM. Dental stem cells and their potential role in apexogenesis and apexification. Int Endodontic J. 2009;42(11):955-962. https//dx.doi. org/10.1111/j.1365-2591.2009.01622.x

10. Kaneko $R$, Akita $H$, Shimauchi $H$, Sasano $Y$. Immunohistochemical localization of the STRO-1 antigen in developing rat teeth by light microscopy and electron microscopy. J Electron Microsc (Tokyo). 2009;58(6):363-373. https//dx.doi.org/10.1093/jmicro/dfp029

11. Sonoyama W, Liu Y, Yamaza T, Tuan RS, Wang S, Shi S, et al. Characterization of the apical papilla and its residing stem cells from human immature permanent teeth: a pilot study. J Endod. 2008;34(2):166-171. https//dx.doi.org/10.1016/j. joen.2007.11.021

12. Miura M, Gronthos S, Zhao M, Lu B, Fisher LW, Robey PG, et al. SHED: stem cells from human exfoliated deciduous teeth. Proc Natl Acad Sci USA. 2003;100(10):5807-5812. https// dx.doi.org/10.1073/pnas.0937635100

13. Harada M, Kenmotsu S, Nakasone N, Nakakura-Ohshima $\mathrm{K}$, Ohshima $\mathrm{H}$. Cell dynamics in the pulpal healing process following cavity preparation in rat molars. Histochem Cell Biol. 2008;130(4):773-783. https//dx.doi.org/10.1007/s00418008-0438-3

14. Andoh E, Kawano Y, Ajima H, Nozawa-Inoue K, Kohno S, Maeda T. Expression of $25 \mathrm{kDa}$ heat shock protein by synovial type B cells of the mouse temporomandibular joint. Arch Oral Biol. 2001;46(10):947-954. https//dx.doi.org/10.1016/ s0003-9969(01)00052-8
15. Jakob U, Gaestel M, Engel K, Buchner J. Small heat shock proteins are molecular chaperones. J Biol Chem. 1993;268(3):1517-1520.

16. Stahl J, Wobus AM, Ihrig S, Lutsch G, Bielka H. The small heat shock protein hsp25 is accumulated in P19 embryonal carcinoma cells and embryonic stem cells of line BLC6 during differentiation. Differentiation: Res Biol Diversity. 1992;51:33-37.

17. Nakasone $\mathrm{N}$, Yoshie $\mathrm{H}$, Ohshima $\mathrm{H}$. The relationship between the termination of cell proliferation and expression of heatshock protein-25 in the rat developing tooth germ. Eur J Oral Sci. 2006;114(4):302-309. https//dx.doi.org/10.1111/j.16000722.2006.00362.x

18. Nakasone N, Yoshie H, Ohshima H. An immunohistochemical study of the expression of heat-shock protein-25 and cell proliferation in the dental pulp and enamel organ during odontogenesis in rat molars. Arch Oral Biol. 2006; 51:378386. https//dx.doi.org/10.1016/j.archoralbio.2005.09.007

19. Sens DA, McGuirt JP, Khan W, Todd JH, Howell RM. Expression of heat shock protein 27 in adult human third molar dental pulp. J Oral Pathol Med. 1996;25(7):382-387.

20. Blau HM, Brazelton TR, Weimann JM. The evolving concept of a stem cell: entity or function? Cell. 2001;105:829-841. https//dx.doi.org/10.1016/s0092-8674(01)00409-3

21. Mayhall EA, Paffett-Lugassy N, Zon LI. The clinical potential of stem cells. Curr Opin Cell Biol. 2004;16:713-720. https// dx.doi.org/10.1016/j. ceb.2004.09.007

22. Pittenger MF, Mackay AM, Beck SC, Jaiswal RK, Douglas $\mathrm{R}$, Mosca JD, et al. Multilineage potential of adult human mesenchymal stem cells. Science. 1999;284(5411):143-147.

23. Barry FP, Murphy JM. Mesenchymal stem cells: clinical applications and biological characterization. Int J Biochem Cell Biol. 2004;36(4):568-584. https//dx.doi.org/10.1016/j. biocel.2003.11.001

24. Kovalchin JT, Wang R, Wagh MS, Azoulay J, Sanders M, Chandawarkar RY. In vivo delivery of heat shock protein 70 accelerates wound healing by up-regulating macrophage-mediated phagocytosis. Wound Repair Regen. 2006;14(2):129-137. https//dx.doi.org/10.1111/j.17436109.2006.00102.x

25. Otsuka Y, Nakakura-Ohshima K, Noda T, Maeda T, Ohshima $\mathrm{H}$. Possible role of heat shock protein (Hsp) 25 in the enamel organ during amelogenesis in the rat molar. Arch Histol Cytol. 2001;64(4):369-378. https//dx.doi.org/10.1679/aohc.64.369

26. Dammaschke T. Rat molar teeth as a study model for direct pulp capping research in dentistry. Lab Anim. 2010;44(1):1-6. https//dx.doi.org/10.1258/la.2009.008120

Received on: 29/2/2020 Final version resubmitted on: 12/4/2020 Approved on: 2/6/2020 